\title{
The role of apoptosis in the development of AGM hematopoietic stem cells revealed by Bcl-2 overexpression
}

\author{
Claudia Orelio, Kirsty N. Harvey, Colin Miles, Robert A. J. Oostendorp, Karin van der Horn, and Elaine Dzierzak
}

\begin{abstract}
Apoptosis is an essential process in embryonic tissue remodeling and adult tissue homeostasis. Within the adult hematopoietic system, it allows for tight regulation of hematopoietic cell subsets. Previously, it was shown that B-cell leukemia 2 (Bcl-2) overexpression in the adult increases the viability and activity of hematopoietic cells under normal and/or stressful conditions. However, a role for apoptosis in the embryonic hematopoietic system has not yet been established. Since the first hematopoietic stem cells
\end{abstract}

(HSCs) are generated within the aortagonad-mesonephros (AGM; an actively remodeling tissue) region beginning at embryonic day 10.5 , we examined this tissue for expression of apoptosisrelated genes and ongoing apoptosis. Here, we show expression of several proapoptotic and antiapoptotic genes in the AGM. We also generated transgenic mice overexpressing Bcl-2 under the control of the transcriptional regulatory elements of the HSC marker stem cell antigen-1 (Sca1), to test for the role of cell survival in the regulation of AGM HSCs. We provide evidence for increased numbers and viability of Sca-1 ${ }^{+}$cells in the AGM and subdissected midgestation aortas, the site where HSCs are localized. Most important, our in vivo transplantation data show that Bcl-2 overexpression increases AGM and fetal liver HSC activity, strongly suggesting that apoptosis plays a role in HSC development. (Blood. 2004;103: 4084-4092)

(c) 2004 by The American Society of Hematology

\section{Introduction}

The hematopoietic system of adult mammals has its foundation in rare hematopoietic stem cells (HSCs) harbored in the bone marrow (BM). These cells are highly potent, contributing to the billions of mature hematopoietic cells in the blood and hematopoietic tissues throughout the lifetime of the individual. ${ }^{1,2}$ In the mouse embryo, the first HSCs are autonomously generated in the aorta-gonadmesonephros $(\mathrm{AGM})^{3}$ region. The onset of HSC activity occurs at embryonic day 10.5 (E10.5) in the AGM, and HSC activity increases from E11 until E14 in the liver. ${ }^{3-7}$ Thereafter, the number of HSCs generally remains constant throughout life. ${ }^{8,9}$

The signals and processes by which HSCs are generated, expanded, and/or maintained in embryonic, fetal, and adult stages are largely unknown. The fact that HSC numbers increase significantly in the midgestation mouse, while remaining constant in the adult, suggests that there are differences in the processes controlling HSC numbers at different times in ontogeny. ${ }^{3,5}$ Although temporally limited hematopoietic cell fate determination processes and HSC proliferation may be primarily responsible for increasing numbers of HSCs in the midgestation embryo, it is possible that the balance between programmed cell death and survival plays an additional role in the quantitative increase in HSCs.

Programmed cell death, or apoptosis, is a highly conserved process involved in adult tissue homeostasis (as reviewed Evan and Littlewood $^{10}$ and Meier et $\mathrm{al}^{11}$ ) and, within embryos in the remodeling of the limbs, kidney, and other structures. ${ }^{11,12}$ Important regulators of apoptosis are the B-cell leukemia 2 (Bcl-2) family of proteins; the proapoptotic $\mathrm{Bcl}-2-$ associated $\mathrm{X}(\mathrm{Bax})$ and $\mathrm{Bcl}-2$ homology 3 (BH3) subfamilies (which includes Bcl-2 interacting mediator of cell death [Bim]), and the antiapoptotic Bcl-2 subfamily (including Bcl-2 and Bcl-x), which promotes cell survival. ${ }^{13}$ It is thought that proapoptotic and antiapoptotic proteins counteract each other's function via protein-protein interactions (reviewed in Bouillet et $\mathrm{al}^{14}$ and Strasser et $\mathrm{al}^{15}$ ). Hence, appropriately controlled temporal and spatial expression of proapoptotic and antiapoptotic proteins is a prerequisite for normal tissue development. ${ }^{11,16-18}$

Within the adult hematopoietic system, $\mathrm{Bcl}-2$ and $\mathrm{Bcl}-\mathrm{x}$ are expressed in immature hematopoietic and lymphoid cells (especially mature thymocytes). ${ }^{19-23}$ Overexpression of Bcl-2 in T cells increases cell survival and decreases negative selection, ${ }^{24-26}$ suggesting a role for $\mathrm{Bcl}-2$ in the thymocyte selection process. Apart from the lymphoid system, the role of apoptosis in the regulation of hematopoietic progenitor and stem cells is far less understood. A number of studies have investigated the role of apoptosis in adult BM HSCs using transgenic mouse models in which $\mathrm{Bcl}$-2 overexpression is directed with the use of the hematopoietic specific $v a v$ promoter $^{27}$ or by use of the more general/ubiquitous $H-2 \mathrm{~K}$ promoter. ${ }^{9,28}$ In both cases, overexpression of $\mathrm{Bcl}-2$ within the HSC/hematopoietic progenitor compartment resulted in enhanced cell survival and radio-resistance of these cells.9,27,28 However, these studies were limited to the analysis of adult and fetal
From the Department of Cell Biology and Genetics, Erasmus University Medical Centre, Rotterdam, The Netherlands; Institute of Human Genetics, International Centre for Life, Newcastle-upon-Tyne, United Kingdom; and Labor für Stammzellphysiologie, III Medizinische Klinik und Poliklinik, Klinikum Rechts der Isar, Technische Universität München, Munich, Germany.

Submitted June 6, 2003; accepted January 29, 2004. Prepublished online as Blood First Edition Paper, February 12, 2004; DOI 10.1182/blood-2003-06-1827.

Supported by the Medical Research Council (MRC) (National Institute for Medical Research [NIMR], London, United Kingdom); HFSP (RG00345/1999M); Erasmus Breedtestrategie Program; the National Institutes of Health $(\mathrm{NIH})$
(R01 DK51077); and Nederlandse Kankerbestrijding (2001-2442).

C.O. and K.N.H. contributed equally to this work.

Reprints: Elaine Dzierzak, Erasmus University Medical Centre, Department of Cell Biology and Genetics, PO Box 1738, 3000 DR Rotterdam, The Netherlands; e-mail: e.dzierzak@erasmusmc.nl.

The publication costs of this article were defrayed in part by page charge payment. Therefore, and solely to indicate this fact, this article is hereby marked "advertisement" in accordance with 18 U.S.C. section 1734.

(C) 2004 by The American Society of Hematology 
hematopoietic cells and did not study the effects of $B c l-2$ overexpression in AGM HSCs.

Since extensive tissue remodeling is ongoing in the AGM region at the time when HSCs first emerge within the midgestation mouse embryo, we set out to specifically analyze apoptosis in AGM HSCs. We show here, within the midgestation AGM and more specifically the aorta, that both proapoptotic and antiapoptotic genes are normally expressed as the AGM is generating HSCs. To further investigate the role of apoptosis in HSC development, we specifically directed overexpression of $\mathrm{Bcl}-2$ to $\mathrm{HSCs}$ in the AGM using the transcriptional control elements of the commonly used stem cell antigen-1 (Sca-1) HSC marker. ${ }^{29,30}$ We have previously demonstrated that these $S c a-1$ (Ly-6E/A) control elements faithfully express reporter genes in the first functional repopulating HSCs from the midgestation dorsal aorta (the specific AGM site of the first emerging HSCs). ${ }^{31-35}$ Here we show that Ly-6E/A-directed $B c l-2$ overexpression results in increased numbers of $\mathrm{Sca}^{-}{ }^{+}$and $\mathrm{c}-\mathrm{kit}^{+}$cells in the AGM, in increased survival of AGM HSCs, and, most importantly, in increased AGM HSC activity. These data strongly suggest that apoptosis plays an important role in the regulation of HSCs beginning at the earliest stages of HSC development in the AGM.

\section{Materials and methods}

\section{Generation of transgenic mice}

An 865-bp murine $B c l-2$ cDNA fragment ${ }^{36}$ was inserted in the Ly-6E expression cassette. ${ }^{31,37,38}$ The 14.9-kb NotI linearized fragment was microinjected into $(\mathrm{CBA} \times \mathrm{C} 57 \mathrm{BL} / 10) \mathrm{F}_{1}$ oocytes. Out of 17 founder mice born, 6 transmitted the transgene, and 2 lines were used for further studies. Bcl-2 transgenic mice appeared normal, and the total body weight was unchanged from that of the wild-type littermates (Table 3). Matings were set up between $B c l-2$ transgenic males and $(\mathrm{CBA} \times \mathrm{C} 57 \mathrm{BL} / 10) \mathrm{F}_{1}$ females. The day of the vaginal plug was counted as day 0 . Pregnant mice were killed by cervical dislocation, and embryos were collected in phosphate-buffered saline (PBS)/10\% fetal calf serum (FCS). Animals were housed according to institutional guidelines (Experimental Dieren Centrum, Erasmus University Medical Center), and animal procedures carried out in compliance with the Standards for Humane Care and Use of Laboratory Animals.

\section{Genotyping, copy number determination, and expression analysis}

For Bcl-2 and YMT genotyping (myogenin [Myo] control), polymerase chain reaction (PCR) conditions were as follows: 100 to $200 \mathrm{ng}$ DNA; 100 ng each primer (Table 1); $1 \times$ buffer; $0.2 \mathrm{mM}$ deoxynucleoside triphos- phate (dNTP); and $1 \mathrm{U}$ AmpliTaq (Applied Biosystems, Foster City, CA), with cycling for 5 minutes at $92^{\circ} \mathrm{C}, 30 \times\left(40\right.$ seconds at $92^{\circ} \mathrm{C}, 40$ seconds at $60^{\circ} \mathrm{C}, 1$ minute at $72^{\circ} \mathrm{C}$ ), and 7 minutes at $72^{\circ} \mathrm{C}$.

For copy number analysis, a Southern blot with 10 to $20 \mu \mathrm{g}$ HindIII-digested genomic DNA was probed with a nick-translated (Amersham Pharmacia Biotech, Piscataway, NJ) ${ }^{32} \mathrm{P}-$-labeled 865-bp Bcl-2 fragment. Analysis was performed by phosphorimaging (Molecular Dynamics, Piscataway, NJ) and ImageQuant software (Amersham Pharmacia Biotech).

For Northern blot analysis, $20 \mu \mathrm{g}$ RNA isolated from several tissues with TRIZOL (Invitrogen/Life Technologies, Carlsbad, CA) was blotted against Genescreen membrane (NEN Life Science Products, Boston, MA). The blot was probed with a ${ }^{32} \mathrm{P}$-labeled 865 -bp $\mathrm{Bcl}-2 \mathrm{cDNA}$ fragment. Ly6 and glyceraldehyde-3-phosphate dehydrogenase $(G A P D H)$ probes are as described previously. ${ }^{31}$

For reverse-transcription PCR (RT-PCR) analysis, embryos were (sub) dissected and tissues stored in RNAlater (Ambion, Austin, TX) at $4{ }^{\circ} \mathrm{C}$. Embryos were genotyped, and tissues from similar genotypes were pooled and homogenized in TRIZOL. RNA was isolated according to manufacturers' instructions. We used 1 to $5 \mu \mathrm{g}$ DNase-treated RNA (RQ1 RNase free DNase; Promega, Madison, WI) for cDNA synthesis with Superscript II Reverse Transcriptase (Invitrogen/Life Technologies). RT-PCR was performed in a $50-\mu \mathrm{L}$ vol with $100 \mathrm{ng}$ each primer (Table 1), $0.2 \mathrm{mM}$ dNTP, AmpliTag, and buffer (Perkin Elmer, Shelton, CT), together with a 40 to 100 ng RNA equivalent of cDNA. Cycling conditions were as follows: 5 minutes at $92^{\circ} \mathrm{C} ; 28$ to $30 \times\left(40\right.$ seconds at $92^{\circ} \mathrm{C}, 40$ seconds at $58^{\circ} \mathrm{C}, 1$ minute at $72^{\circ} \mathrm{C}$ ); and 7 minutes at $72^{\circ} \mathrm{C}$. PCR products were run on $1.2 \%$ agarose $/ 1 \times$ Tris-borate-EDTA (tris(hydroxymethyl)aminomethane-borateethylenediaminetetraacetic acid) (TBE) gels with ethidium bromide (EtBr) and scanned on a Typhoon scanner (Molecular Dynamics).

For Western blot analysis, protein extracts from several adult tissues were made in Laemmli buffer, separated on a $10 \%$ sodium dodecyl sulfate (SDS) polyacrylamide gel, and blotted to polyvinylidene difluoride (PVDF) membrane (Millipore, Billerica, MA). Blots were blocked and incubated with an anti-Bcl-2 antibody (Alexis Biochemicals, San Diego CA) in 2\% milk/Tris-buffered saline-Tween (TBS-T) followed by an antirabbithorseradish peroxidase (HRP) antibody (DAKO, Carpinteria, CA) and enhanced chemiluminescence (ECL) detection.

\section{Survival and cell viability assays}

Healthy transgenic and nontransgenic littermates mice of 7 to $13(\operatorname{Ln} 2)$ and 8 to 22 ( $\operatorname{Ln} 479$ ) weeks of age were randomly divided into 3 pools, which received equal split doses of $10.5,9.5$, or 8.5 Gy $\gamma$-irradiation. Mice received antibiotics and were checked daily for survival.

Whole BM cells from $\mathrm{Bcl}$-2 transgenic and nontransgenic littermates were collected in PBS/10\% FCS, suspended as single cells, and counted (Beckman Coulter, Fullerton, FL). BM cells were seeded at a cell density of $2 \times 10^{5} / \mathrm{mL}$ in Dulbecco Modified Eagle medium (DMEM) $/ 10 \%$ FCS/

Table 1. Primer sequences

\begin{tabular}{|c|c|c|c|}
\hline Primer & Primer sequence, $5^{\prime} \rightarrow 3^{\prime}$ & $\begin{array}{l}\text { Sequence or reference } \\
\text { on which this was based }\end{array}$ & $\begin{array}{l}\text { PCR fragment } \\
\text { length, bp }\end{array}$ \\
\hline BC2PE & GTGCAGCTGACTGGACATCTCTGC & Miles et $\mathrm{al}^{31}$; Negrini et $\mathrm{al}^{39}$ & 450 \\
\hline PE5 & АCTCTGCCTGCAACCTTGTCTGAG & Miles et $\mathrm{al}^{31}$; Negrini et $\mathrm{al}^{39}$ & 450 \\
\hline YMT2-1 & CTGGAGCTCTACAGTGATGA & Medvinsky and Dzierzak ${ }^{3}$ & 342 \\
\hline YMT2-2 & CAGTTACCAATCAACACATCAC & Medvinsky and Dzierzak ${ }^{3}$ & 342 \\
\hline Myo-1 & TTACGTCCATCGTGGACAGC & Müller et $\mathrm{al}^{4}$ & 245 \\
\hline Мyo-2 & TGGGCTGGGTGTTAGTCTTA & Müller et $\mathrm{al}^{4}$ & 245 \\
\hline $\mathrm{mBcl}-2$ forward & GCACAGATGTCCAGTCAGCTG & NM_009741 & 268 \\
\hline $\mathrm{mBcl}-2$ reverse & GCCATATAGTTCCACAAAGGC & NM_009741 & 268 \\
\hline $\mathrm{mBcl}-\mathrm{x}$ forward & GGCGATGAGTTTGAACTGCG & U51278 & 915 \\
\hline $\mathrm{mBcl}-\mathrm{x}$ reverse & CCTCACTCAATGGCTCTTGG & U51278 & 915 \\
\hline mBim forward & GAGAAGGTGGACAATTGCAG & AF032461 & 290,380 \\
\hline mBim reverse & GCCTTCTCCATACCAGACGG & AF032461 & 290,380 \\
\hline beta-actin forward & CCTGAACCCTAAGGCCAACCG & X03672 & 398 \\
\hline beta-actin reverse & GCTCATAGCTCTTCTCCAGGG & X03672 & 398 \\
\hline
\end{tabular}


penicillin (Pen)/streptomycin (Strep) at $37^{\circ} \mathrm{C}, 5 \% \mathrm{CO}_{2}$. At 1, 2, 4, 8, and 11 days, viable cell counts were determined by trypan blue exclusion.

\section{FACS analysis, immunostaining, and TUNEL staining}

AGM and liver tissues were dissected, and explant cultures for 3 to 4 days were performed as described previously. ${ }^{3,5}$ During the culture period, embryos were genotyped, and tissues with similar genotypes pooled. Before staining, tissues were collagenase treated as described. BM cells were made directly into a single-cell suspension. Cell staining was done in PBS/10\% FCS with fluorescein isothiocyanate (FITC)- or phycoerythrin (PE)-conjugated antibodies against Sca-1, c-kit, CD4, CD8, CD11b (macrophage antigen-1 [Mac-1]), Ly-6G(Gr1), B220, and annexin V (Pharmingen, Franklin Lanes, NJ), and fluorescence was measured on a FACScan or FACSVantage (Becton Dickinson, Franklin Lanes, NJ). Dead cells were excluded by 7-amino-actinomycin D (7AAD) or Hoechst 33258 (Molecular Probes, Eugene, OR) staining.

For immunofluorescence, single-cell suspensions from AGM cells from Ly6A-green fluorescent protein (GFP) embryos were made. Cytospin cells were fixed (2\% paraformaldehyde/PBS) and stained with Bcl-2 antibody and $\alpha$-rabbit-Texas Red or cyanine 3.18 (Cy3) secondary antibody.

Embryos were frozen in Tissue-Tek (Sakura Finetek USA, Torrance, CA) and cryosectioned $(7-8 \mu \mathrm{M})$. transferase-mediated deoxyuridine triphosphate nick end labeling (TUNEL) staining was performed with the in situ cell death detection kit/peroxidase (POD) (Roche, Indianapolis, IN) on the basis of the manufacturer's instructions. Staining was visualized with peroxidase substrate AEC (3-amino-9-ethylcarbazde), and sections were dehydrated and embedded in Entallan (Merck, West Point, PA).

\section{In vivo repopulation assays for HSCs}

For all transplantations, male donor cells were injected intravenously into $(\mathrm{CBA} \times \mathrm{C} 57 \mathrm{BL} / 10) \mathrm{F}_{1}$ females irradiated with a 9.5-Gy split dose of $\gamma$-irradiation. Repopulation was assayed at 1 and 4 months after transplantation by a Y-chromosome (YMT)-specific PCR on peripheral blood DNA. Multilineage repopulation was analyzed on several recipients either by PCR on DNA from hematopoietic tissues or as described previously. ${ }^{40}$

Donor male $\mathrm{Bcl}-2$ transgenic and nontransgenic littermates (10 weeks old) were killed, and BM cells collected and injected into recipients at several cell doses in combination with $10^{5}$ female competitor BM cells. For repopulation assays on E11 and E12 AGM and liver cells, tissues were dissected and collagenase treated $(0.125 \%)$ in PBS/10\% FCS. Then, 0.3 embryo equivalents (ee) AGM cells (approximately $2 \times 10^{5} /$ ee for E11; approximately $3 \times 10^{5} / \mathrm{ee}$ for E12) or 0.03 to 0.003 ee liver cells (approximately $3 \times 10^{6} / \mathrm{ee}$ for E12) were injected with $2 \times 10^{5}$ female spleen cells into recipients. For secondary transplantations, BM was collected from reconstituted primary recipients, and $10^{5}$ cells were injected into secondary recipients. Secondary recipients receiving BM from primary recipients injected with E12 AGM or liver were coinjected with $10^{5}$ female $\mathrm{BM}$ cells.

\section{Results}

\section{Expression of proapoptotic and antiapoptotic regulators in the midgestation aorta}

To date, little is known concerning the expression of proapoptotic and antiapoptotic regulators in the midgestation AGM region and particularly HSCs. To examine whether apoptosis normally occurs in the AGM, TUNEL analysis was performed on transverse sections through the truncal regions of midgestation embryos. Several TUNEL ${ }^{+}$foci are found scattered throughout the representative E11 truncal section shown in Figure 1A. In the AGM region, many highly positive foci are found in the mesonephic tubules of the urogenital ridges (UGRs), while only one strongly positive focus was found a short distance from the dorsal side of the dorsal aorta (Figure 1B). However, many diffuse individually weak
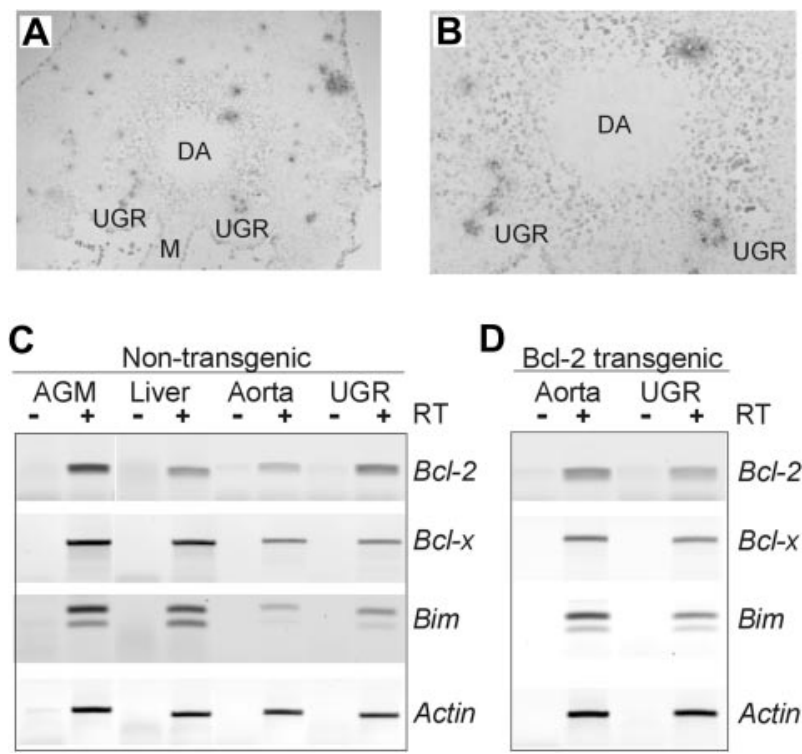

D Bcl-2 transgenic

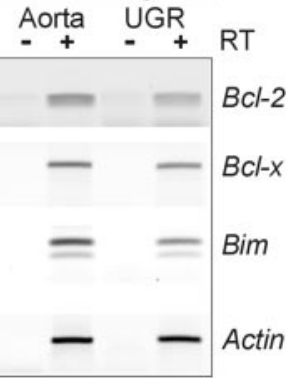

Figure 1. Apoptotic foci and apoptosis-related gene expression in the E11 AGM TUNEL staining was performed on transverse sections from the truncal region of an E11 embryo to localize apoptotic cells in the AGM region. (A-B) A representative section is shown at $10 \times$ magnification $(A)$ and at $40 \times$ magnification (B). TUNEL (black/gray) foci and diffuse scattered individual cells are observed. DA indicates lumen of dorsal aorta; UGR, urogenital ridge; $M$, mesentery. TUNEL staining was performed 3 times on 2 wild-type and $2 \mathrm{Bcl}-2$ transgenic embryos. No obvious difference in the TUNEL staining pattern was observed when sections from $\mathrm{Bcl}-2$ transgenic embryos were compared to sections from nontransgenic embryos. (C) Expression of the antiapoptotic genes $\mathrm{Bcl}-2$ and $\mathrm{BCl}-x$ and the proapoptotic Bim gene in the E11 AGM, aorta, UGRs, and liver region of a nontransgenic embryo. RT-PCR analysis was performed on cDNAs made from the indicated midgestation tissues. Signal intensity from the actin PCR fragment was used as a normalization control. Note that, as expected, the Bim primers amplify 2 different transcript isoforms (splice variants). (D) RT-PCR analysis of a $\mathrm{BCl}-2$ transgenic embryo reveals altered levels of $B C l-2, B C l-x$, and Bim gene expression in the E11 aorta and UGR. RT-PCR analysis was performed 3 times and confirmed on 3 independent sets of cDNAs.

TUNEL $^{+}$cells are also found surrounding the dorsal aorta, suggesting that apoptotic processes are occurring throughout the AGM region during midgestation.

The expression of antiapoptotic genes $B c l-2$ and $B c l-x$ and the proapoptotic gene Bim in the whole AGM, aorta, UGRs, and liver was examined by semiquantitative RT-PCR. As shown in Figure $1 \mathrm{C}, \mathrm{Bcl}$-2 expression is approximately 2-fold higher in the E11 AGM as compared with the E11 liver. Similar results were obtained with E12 tissues (not shown). In the E11 AGM, Bcl-2 is expressed in both the aorta and the UGR, with a higher level of expression in the UGR. Bcl-x and Bim expression levels are comparable in the E11 AGM, and liver, with Bim expression appearing to be slightly higher in the UGR than in aorta. Thus, both antiapoptotic and proapoptotic genes are expressed in the embryonic sites (aorta and liver) harboring the earliest HSCs.

To determine if Bcl-2 is normally expressed in AGM HSCs, immunostaining was performed on cytospins of E12 Ly-6A (Sca-1) GFP transgenic AGM cells. Previous studies in such transgenic embryos $^{31-35}$ have shown that all AGM HSCs are GFP ${ }^{+}$. When we performed Bcl-2-specific antibody staining on such cytospins, we observed Bcl-2 expression in many AGM cells (Figure 2C), among which are $\mathrm{GFP}^{+}$cells (Figure $2 \mathrm{~B}$ ). $\mathrm{AGM} \mathrm{GFP}^{+}$cells include aortic HSCs and endothelial and mesonephric tubule cells. ${ }^{34}$ Overlay of the 2 fluorescent signals shows that the $\mathrm{GFP}^{+}$cells coexpress the Bcl-2 protein (Figure 2D). To exclude the $\mathrm{GFP}^{+}$mesonephric cells, cytospins from subdissected E11 aortas were immunostained with the Bcl-2 antibody. Figure 2F-H shows expression of Bcl-2 in all $\mathrm{GFP}^{+}$cells, which include only HSCs and endothelial cells. Bcl-2 
Figure 2. Expression of $\mathrm{Bcl}-2$ by $\mathrm{Sca}-\mathbf{1}^{+} \mathrm{AGM}$ cells. Immunostaining was performed on $L y-6 A$ (Sca-1) GFP transgenic E12 AGM and E11 aortic cells. AGM and aorta cells were isolated as a single-cell suspension and deposited on microscope slides by cytospin (original magnification, $\times 100$ ). Panels $A, E$, and I show 4',6-diamidino-2-phenylindole (DAPI) staining; panels B, F, and $J$ show Ly-6A (Sca-1) GFP fluorescence; panel C shows anti-Bcl-2 Texas Red fluorescence; and panel $\mathrm{G}$ shows anti-Bcl-2 Cy3 fluorescence. Panel $\mathrm{K}$ was incubated with no primary antibody. Panels D, H, and L are an overlay of GFP and Texas Red/Cy3 fluorescence. Panels A-D are a cytospin of E12 AGM cells stained with anti-Bcl-2 antibody conjugated with Texas Red. Panels E-H show a cytospin of $E 11$ aorta cells stained with anti-Bcl-2 antibody conjugated with Cy3. Panels I-L show a cytospin of E11 AGM cells incubated with no primary antibody.
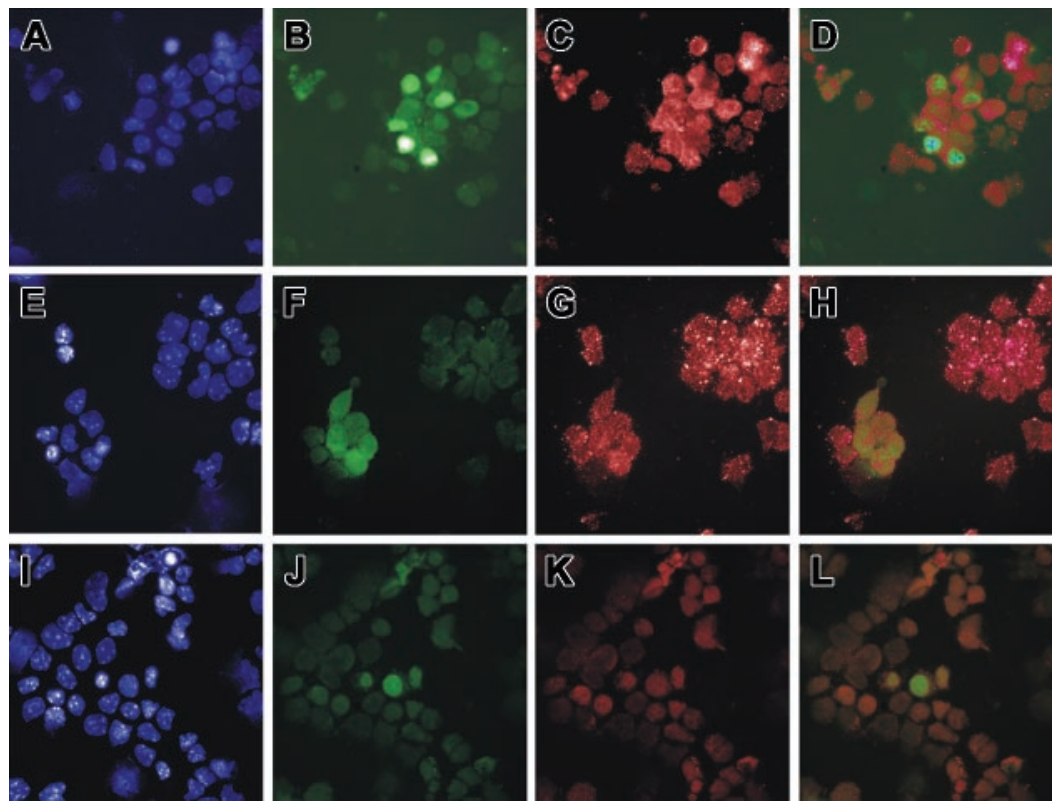

expression in such cells was confirmed by RT-PCR analysis on sorted c-kit ${ }^{+}$AGM cells (c-kit is a marker for HSCs but not mesonephric cells $)^{41}$ (not shown). Taken together, these data indicate that apoptosis is taking place within the AGM and that Bcl-2 is expressed in aortic and AGM HSCs and/or endothelial cells.

\section{Sca-1 Bcl-2 transgenic mice overexpress $\mathrm{Bcl}-2$ in hematopoietic cells}

To study whether apoptotic/cell survival processes are functional within the embryonic hematopoietic system, we generated transgenic mice in which overexpression of the antiapoptosis gene $\mathrm{Bcl}-2$ was directed by the $S c a-1$ ( $L y-6 E$ ) transcriptional control elements. A $B c l-2$ cDNA fragment ${ }^{36}$ was inserted into the first untranslated exon of the 14-kb Ly-6E genomic fragment ${ }^{31,38}$ (Figure $3 \mathrm{~A}$ ), and 2 transgenic lines ( $\operatorname{Ln} 2$ and $\operatorname{Ln} 479$ ) were analyzed in detail. The copy number was determined by Southern blot analysis, comparing signal intensity of the endogenous $1.4-\mathrm{kb} \mathrm{Bcl}-2$ gene fragment to the 4.7-kb transgenic $\mathrm{Bcl}-2$ band (Figure 3B). The transgene copy numbers of Ln 2 and Ln 479 are 7 and 20, respectively. Northern blot analysis demonstrated overexpression of the $\mathrm{Bcl}-2$ transgene in kidney, liver (Figure 3C), thymus, and spleen (data not shown). Western blotting revealed that $\mathrm{Bcl}-2$ protein expression was also elevated in transgenic animals (Figure 3D). Only low or undetectable levels of endogenous Bcl-2 protein were found in wild-type littermates, consistent with low mRNA expression in the wild type. Thus, the Sca-1 transcriptional regulatory elements direct $\mathrm{Bcl}-2$ expression at high levels in several hematopoietic and nonhematopoietic tissues in the transgenic animals, and this expression pattern correlates with the Ly-6E/A expression pattern as previously reported..$^{31-35}$

\section{$\mathrm{Bcl}-2$ overexpression results in radio-protection and increased hematopoietic cell viability in the adult}

To test the validity of our transgenic model, we examined the effects of $\mathrm{Bcl}-2$ overexpression in the adult hematopoietic system. We performed survival experiments to assess whether Sca-1directed Bcl-2 overexpression could protect cells from radiationinduced apoptosis in vivo. Transgenic animals and normal littermates were challenged with different doses of total body $\gamma$-irradiation, and the number of viable animals was determined daily for up to 30 days. At doses of 10.5 (Figure 4A), 9.5, and 8.5 Gy (not shown), both Ln 479 and Ln 2 (not shown) transgenic animals showed higher survival rates at day 30 in comparison with their wild-type littermates.

To test whether this increased survival could be related to protection of cells of the hematopoietic system from apoptosis, we performed in vitro experiments using BM (Figure 4B) cells from $\mathrm{Bcl}-2$ transgenic and wild-type littermates. Over a period of 11

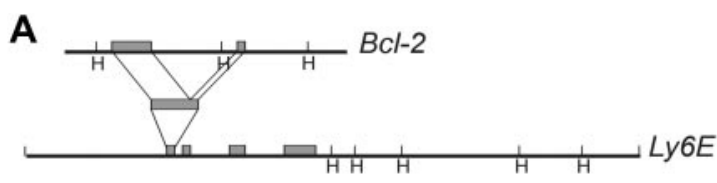

B
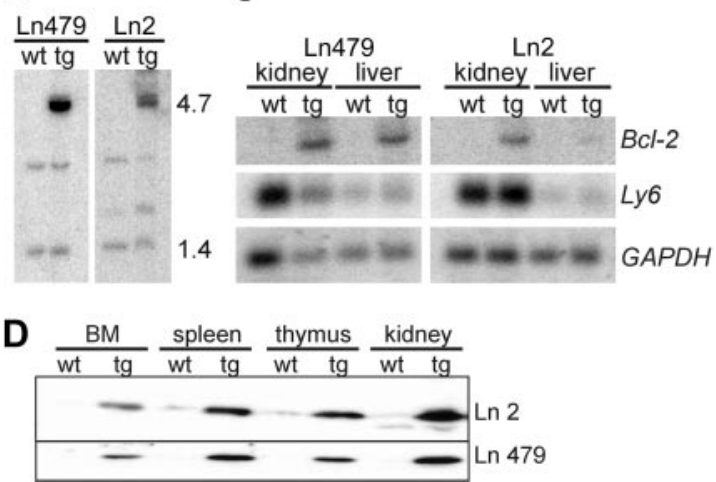

Figure 3. Overexpression of $\mathrm{Bcl}-2$ in hematopoietic tissues of Sca-1 Bcl-2 transgenic mice. (A) Transgene construct. An 865-bp murine Bcl-2 cDNA fragment was inserted into exon one of a 14-kb Sca-1 (Ly-6E) expression cassette. $\mathrm{H}$ indicates HindIII. (B) Transgene copy number determination. A Southern blot containing HindllI-digested DNA was probed with a $\mathrm{Bcl}-2$ fragment to reveal the 1.4-kb endogenous gene and 4.7-kb transgene. Ln 479 contains 20 and Ln 2 contains 7 copies of the transgene. (C) Northern blot analysis for $\mathrm{BCl}-2$ transgene expression in several adult tissues. $\mathrm{BCl}-2$ is expressed in liver and kidney in Ln 479 and $\mathrm{Ln} 2 \mathrm{Bcl}-2$ transgenic (tg) animals. (D) Western blot analysis of $\mathrm{Bcl}-2$ protein expression in $\mathrm{Ln} 2$ and $\mathrm{Ln} 479$ transgenic animals. Bcl-2 is overexpressed in several transgenic tissues, including kidney, thymus, spleen, and bone marrow, as compared with nontransgenic (wild-type [wt]) littermates. In general, no obvious abnormalities were found in the transgenic adults. Blood smears showed no morphologic differences or leukemic cells, and hematocrits did not differ between the transgenic and nontransgenic adults (data not shown). 

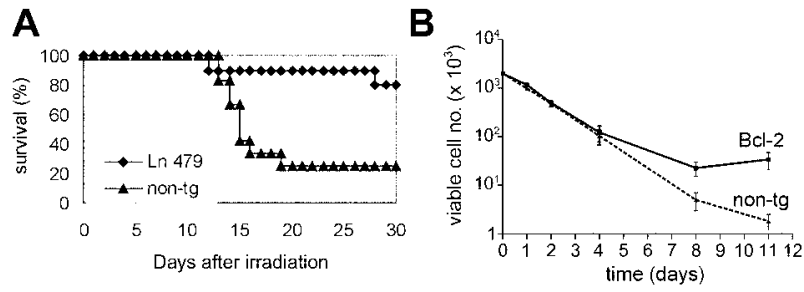

Figure 4. Effects of Bcl-2 overexpression on adult mice and cells. (A) In vivo survival curves of $\mathrm{BCl}-2$ transgenic mice and nontransgenic littermates. Adult mice of 7 to 22 weeks of age were subjected to a split dose of $\gamma$-irradiation of 10.5 Gy. Survival of both Ln 479 (shown) and Ln 2 (not shown) transgenic mice and littermates was checked daily over 30 days. Results are derived from 2 separate experiments for each transgenic line. The number of mice irradiated at 10.5 Gy was $n=10$ for $\operatorname{Ln} 479$ $\operatorname{tg}$ and $n=12$ for wt littermates. For other irradiation doses, 10 to 15 mice were used per group (not shown). (B) Viable cell numbers of BM cells of Ln 479 transgenic (Bcl-2) and a wild-type littermate (non-tg). Bcl-2 overexpression results in higher viable cell numbers in vitro over a period of 11 days. Note that the scale on the $y$-axis is logarithmic. These graphs show a representative experiment out of a total of 5 experiments ( $7 \mathrm{Bcl}-2$ tg and $7 \mathrm{wt}$ littermates ranging 10 to 24 weeks of age). Error bars indicate SEM.

days, in the absence of added hematopoietic growth factors, the survival of nonadherent cells was determined. The number of viable cells derived from $\mathrm{Bcl}-2$ transgenic BM and spleen (not shown) were much greater than those derived from wild-type littermates. Hence, the increased survival rate of the $\mathrm{Bcl}-2$ transgenic mice is due, at least in part, to increased viability of hematopoietic cells.

We next examined whether the increased number of viable cells in these cultures was due to decreased apoptosis by flow cytometric analysis with annexin V (an early marker of apoptosis) and 7AAD staining ${ }^{42}$ (Table 2). Nontransgenic cells cultured under the stressful hematopoietic growth factor-free conditions showed the expected pattern of cell death, with $31 \%$ of cells in the nonviable $\left(7 \mathrm{AAD}^{+}\right)$quadrants. In contrast, $\mathrm{Bcl}-2$ transgenic cultures showed only $4 \% 7 \mathrm{AAD}^{+}$cells, with a much higher percentage of cells in a viable state $\left(91 \%\right.$ annexin $\left.{ }^{-} 7 \mathrm{AAD}^{-}\right)$. The percentage of cells in the early stages of apoptosis (annexin ${ }^{+} 7 \mathrm{AAD}^{-}$) was almost 3 -fold higher in the nontransgenic cultures as compared with the $B c l-2$ transgenic cultures. Thus, Bcl-2 overexpression decreases the number of BM cells entering into apoptosis in growth factor-free hematopoietic cultures, resulting in increased numbers of viable cells.

To investigate whether lower apoptosis/higher cell maintenance was occurring in $\mathrm{Bcl}-2$ transgenic hematopoietic cell subsets that normally express Sca- $1,{ }^{43}$ we examined T- and B-lymphoid cells in the thymus and spleen (Table 3). Increases in the percentages of $\mathrm{CD}^{-} \mathrm{CD}^{-}, \mathrm{CD}^{+}$, and $\mathrm{CD}^{+}$thymocytes and a concomitant large decrease in $\mathrm{CD} 4^{+} \mathrm{CD} 8^{+}$thymocytes are observed in transgenic adults (Table 3 ). Also, the absolute number of mature $\mathrm{CD}^{+}$ and $\mathrm{CD}^{+} \mathrm{T}$ cells in the spleen are increased (2.5- to 4-fold), and a 2 - to 3-fold increase in the absolute number of B220 ${ }^{+}$splenocytes is observed. Taken together, the increases in the absolute number of

Table 2. Percentages of cells obtained after annexin V and 7AAD FACS analysis of $B M$ from transgenic and nontransgenic mice

\begin{tabular}{lccr}
\hline & Annexin-7AAD $^{-}$ & Annexin $^{+}$7AAD $^{-}$ & 7AAD $^{+}$ \\
\hline Nontransgenic & $58.3 \pm 4.7$ & $10.5 \pm 0.1$ & $30.9 \pm 4.7$ \\
Bcl-2 & $91.0 \pm 2.5$ & $3.7 \pm 0.3$ & $4.4 \pm 1.3$ \\
\hline
\end{tabular}

Three transgenic mice ( $\mathrm{n}=2 \mathrm{Ln} 2$ and $\mathrm{n}=1 \mathrm{Ln} 479$; mice aged 9 to 23 weeks) and 3 nontransgenic littermates were used. Differences observed between the transgenic and nontransgenic in the annexin ${ }^{-} 7 A_{A D}^{-}$, annexin ${ }^{+} 7 A A D^{-}$, and $7 A A D^{+}$ subsets are statistically significant as determined by Student $t$ test. Data are presented as mean \pm SEM.
Table 3. Lymphoid tissue and cell subset analysis of nontransgenic and $\mathrm{Bcl}-2$ transgenic adults

\begin{tabular}{|c|c|c|c|c|}
\hline & Nontransgenic & Ln 479 & Nontransgenic & Ln 2 \\
\hline Body weight, $g$ & $29.4 \pm 5.7$ & $29.4 \pm 5.8$ & $31.4 \pm 4.0$ & $32.0 \pm 4.7$ \\
\hline \multicolumn{5}{|c|}{$\begin{array}{l}\text { Absolute cell numbers, } \\
\quad \times 10^{7}\end{array}$} \\
\hline Thymus & $7.7 \pm 1.4$ & $9.4 \pm 1.1$ & $10.8 \pm 4.3$ & $11.1 \pm 3.6$ \\
\hline Spleen & $14.7 \pm 1.6$ & $31.9 \pm 6.4$ & $11.4 \pm 1.1$ & $37.3 \pm 1.9$ \\
\hline \multicolumn{5}{|c|}{ Thymus cell subsets, $\%$} \\
\hline $\mathrm{CD}^{-}{ }^{-} \mathrm{CD} 8^{-}$ & $3.7 \pm 1.0$ & $4.6 \pm 1.7$ & $2.0,3.8^{*}$ & $5.1 \pm 1.7$ \\
\hline $\mathrm{CD}^{+}{ }^{+} \mathrm{CD} 8^{+}$ & $83.5 \pm 3.6$ & $75.6 \pm 4.2$ & $87.8,83.3^{*}$ & $70.9 \pm 5.2$ \\
\hline $\mathrm{CD}^{+}{ }^{+} \mathrm{CD}^{-}$ & $9.9 \pm 3.1$ & $13.7 \pm 2.0$ & $11.9,9.2^{*}$ & $18.8 \pm 2.4$ \\
\hline $\mathrm{CD}^{-}{ }^{-} \mathrm{CD} 8^{+}$ & $3.0 \pm 0.6$ & $6.1 \pm 0.7$ & $1.0,0.9^{*}$ & $5.2 \pm 1.4$ \\
\hline \multicolumn{5}{|c|}{ Spleen cell subsets, $\times 10^{7}$} \\
\hline $\mathrm{CD}^{+}$ & $3.1 \pm 0.6$ & $8.5 \pm 1.1$ & $2.8,1.1^{*}$ & $7.4 \pm 1.9$ \\
\hline $\mathrm{CD}^{+}$ & $1.6 \pm 0.5$ & $4.0 \pm 0.3$ & $1.0,0.5^{\star}$ & $2.8 \pm 1.6$ \\
\hline $\mathrm{B}^{2} 20^{+}$ & $10.0 \pm 0.7$ & $21.4 \pm 5.1$ & $8.0,2.9^{*}$ & $18.6 \pm 2.7$ \\
\hline
\end{tabular}

Tissues were isolated from mice ranging in age from 10 to 20 weeks. Both male and female mice are included in each of the groups. For the total thymus and spleen cell counts, sample numbers are as follows: $\operatorname{Ln} 479$ mice, $n=6$; their nontransgenic littermates, $n=6$; Ln 2 mice, $n=11$; their nontransgenic littermates, $n=7$. For the spleen and thymus subset cell determinations, $n=3$ except for nontransgenic Ln 2 control group. Values are given as mean \pm SEM.

${ }^{*}$ Data represent 2 values $(n=2)$

spleen cells (approximately $17-25 \times 10^{7}$ ) can be accounted for by the increase in the mature lymphocyte $\mathrm{CD} 4^{+}, \mathrm{CD} 8^{+}$, and $\mathrm{B} 220^{+}$ subsets and may be attributed to increased cell survival by overexpression of Bcl-2. Thus, our transgenic animal model results in Bcl-2-induced changes within the expected Sca-1-expressing Tand B-lymphoid subsets of the adult hematopoietic system.

\section{$\mathrm{Bcl}-2$ overexpression results in increased numbers and viability of Sca- $1^{+}$and c-kit ${ }^{+}$cells in the AGM}

An overall examination of cell survival/death within the E11 AGM region of Bcl-2 transgenic embryos by TUNEL staining revealed no obvious changes as compared with wild-type sections. Hence, to determine if Bcl-2 was indeed overexpressed in the AGM, RT-PCR was performed on subdissected E11 AGM Bcl2 trangenic tissues. Gene expression of $B c l-2$, as well as antiapoptotic $B c l-x$ and proapoptotic Bim, was tested. Figure 1D shows representative data from one of several experiments. A 2- to 10-fold increase in $\mathrm{Bcl}-2$ gene expression was consistently observed in the E11 transgenic aorta, as compared with the nontransgenic aorta (Figure 1C). Also, Bim expression is increased (approximately 1.5- to 4-fold), while $B c l-x$ expression remained as in the nontransgenic tissue. Thus, $B c l-2$ is overexpressed within the transgenic E11 aorta (the subregion in which the first HSCs are found).

To determine whether the overexpression of Bcl-2 disrupts the normal balance of apoptosis and survival of phenotypically defined populations of cells containing HSCs, fluorescence-activated cell sorter (FACS) analysis with HSC surface markers c-kit and Sca-1 was performed on cells from E11 control and transgenic AGM explant cultures. As shown in a representative profile of c-kitstained AGM cells (Figure 5A) (gated on nongranular cells), the

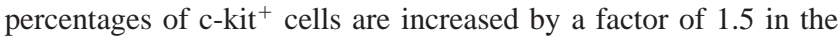
$B c l-2$ transgenic tissues. This was confirmed in several independent experiments, and the data are shown as fold change in percentage, since the absolute number of cells in transgenic and nontransgenic AGMs was comparable. The increase in percentage of c-kit ${ }^{+}$and Sca- $1^{+}$cells in $\mathrm{Bcl}-2 \mathrm{E} 11 \mathrm{AGM}$ explants ranged from 1.5- to 1.9-fold and 1.5- to 2.2-fold, respectively (Figure 2C). To confirm that the increase in percentage of Sca- $1^{+}$cells can in part be due to 
A

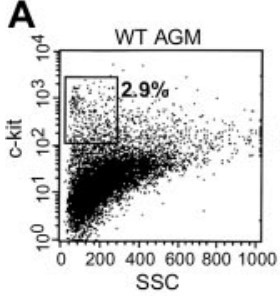

WT Aorta

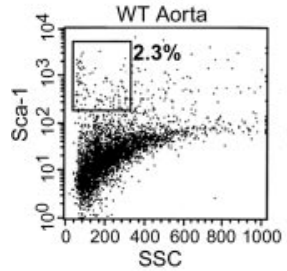

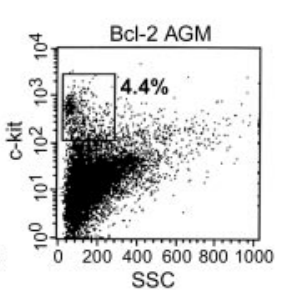

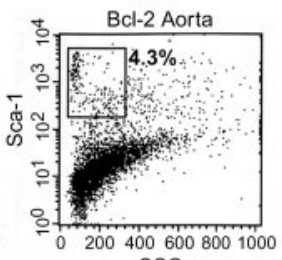

SSC
B
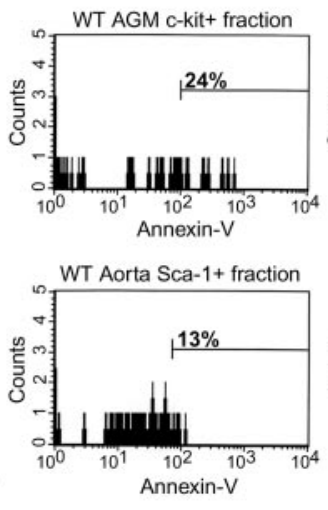

C
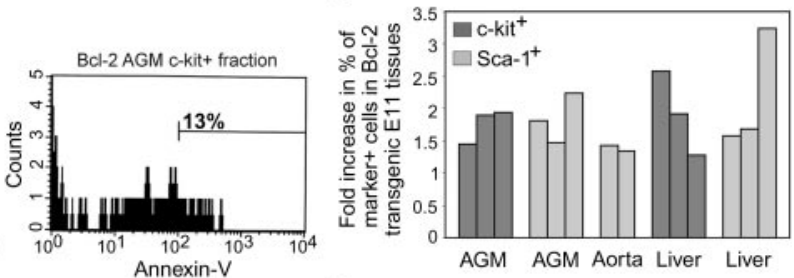

Bcl-2 Aorta Sca-1+ fraction
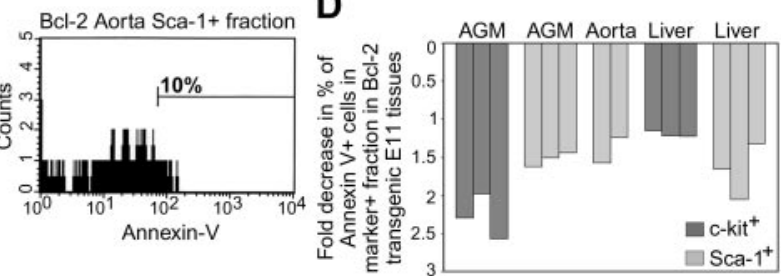

Figure 5. Increased numbers and viability of c-kit ${ }^{+}$and Sca-1+ cells in Bcl-2-overexpressing AGM and liver. E11 AGM, aorta, and liver tissues from Bcl-2 transgenic and nontransgenic embryos were dissected and cultured as explants for 3 to 4 days, during which time the embryos were genotyped. Tissues from embryos with a similar genotype were pooled, and single-cell suspensions were stained with antibodies specific for c-kit or Sca-1 and with annexin V and 7AAD. (A) Representative FACS plots for c-kit- and Sca-1-stained cells (top and bottom rows, respectively) within the 7AAD- fraction of wild-type (WT) and Bcl-2-overexpressing AGM and aorta tissues, respectively. Side scatter (SSC) is shown on the x-axis and fluorescent antibody staining on the $y$-axis. Percentages of c-kit ${ }^{+}$and Sca- $1^{+}$cells are shown for the gated region (HSCs are found within the nongranular side scatter). (B) Within the ${\mathrm{c}-\mathrm{kit}^{+}}^{+}$and $\mathrm{Sca}-1^{+}$fractions of $\mathrm{AGM}$ and aorta tissues, the percentage of annexin $\mathrm{V}^{+}$cells was determined (indicating the percentage of cells entering the apoptotic pathway). Representative histogram plots are shown with indicated percentages of annexin $\mathrm{V}^{+}$cells in the c-kit ${ }^{+}$(top row) or Sca- $1^{+}$ (bottom row) cell fractions, respectively, in the AGM or subdissected aorta. Bcl-2-overexpressing tissues (right panels) contain less annexin $\mathrm{V}^{+}$cells within the $\mathrm{c}^{-k i t^{+}}$and Sca- $1^{+}$fraction. (C) Overview of the fold changes (increases) in percentages of c-kit ${ }^{+}$and Sca- $1^{+}$cells and (D) fold changes (decreases) in percentages of annexin $\mathrm{V}^{+}$cells within the $\mathrm{c}-\mathrm{kit}^{+}$and Sca- ${ }^{+}$fractions of $\mathrm{Bcl}-2$ transgenic $\mathrm{E} 11 \mathrm{AGM}$, aorta, or liver cells as compared with wild-type cells. Percentages were determined as indicated in panels $\mathrm{A}$ and B. Results are shown for 3 experiments with Sca-1 and annexin V, 3 experiments with c-kit and annexin V, and 2 experiments with E11 aorta cells. Each bar in the graph represents an independent experiment containing embryos from 1 to 3 litters. From each experiment, several samples (each contained a pool of cells from 1 to 3 tissues) were measured, and the average of these samples is shown. Total number of events analyzed ranges from $8 \times 10^{4}$ to $2 \times 10^{5}$.

HSCs and not only to mesonephric cells, FACS analysis was performed on subdissected E11 aorta explants. The percentage of Sca- $1^{+}$aorta cells increases 1.9 -fold in the $B c l-2$ transgenic aortas as compared with nontransgenic aortas, strongly suggesting the increase of HSCs. Moreover, similar increases in the percentages of ${\mathrm{c}-\mathrm{kit}^{+}}^{+}$and $\mathrm{Sca}-1^{+}$cells in E11 transgenic liver explants were observed (Figure 5A), strongly suggesting an increase in liver HSCs in transgenic tissues. Thus, as shown with 2 independent HSC markers, c-kit and Sca-1, overexpression of Bcl-2 results in increased numbers of E11 AGM, aorta, and liver cell populations containing phenotypically defined HSCs.

To examine whether the increase in $\mathrm{c}-\mathrm{kit}^{+}$and Sca- $1^{+}$cells is related to decreased apoptosis, we costained with annexin $\mathrm{V}$ and performed cytometric analysis on the gated c-kit ${ }^{+}$and Sca- ${ }^{+}$ fractions of $7 \mathrm{AAD}^{-} \mathrm{AGM}$, aorta, and liver cells. As shown in Figure $5 \mathrm{~B}$, the percentage of annexin $\mathrm{V}^{+}$cells in the c-kit ${ }^{+}$fraction of a $\mathrm{Bcl}-2$ transgenic AGM explant is decreased 1.9-fold as compared with wild-type AGM explants. This decrease ranged from 1.9- to 2.6-fold in Bcl-2 AGM explants and from 1.1- to 1.2-fold in liver explants (Figure 5D). Furthermore, a decrease in the percentage of annexin $\mathrm{V}^{+}$cells (1.2- to 1.6-fold) was found in the Sca- $1^{+}$fraction of aorta explants (although this decrease is less apparent in the histogram, owing to the isolation of fewer cells). Thus, Bcl-2 overexpression leads to a quantitative increase in cell populations containing phenotypically defined HSCs by decreasing the number of these cells entering the apoptotic pathway in midgestation hematopoietic tissues.

\section{Hematopoietic stem cell activity is increased in the AGM of Bcl-2-overexpressing embryos}

To directly test whether Bcl-2 overexpression promotes the viability/ survival and increases the numbers of HSCs, in vivo hematopoietic repopulation analyses were performed, both on adult BM cells and on midgestation AGM and liver cells. Cells obtained from male
$\mathrm{Bcl}-2$ transgenic and nontransgenic adults and E11 and E12 embryos were injected in limiting numbers in vivo into irradiated adult female recipients. Recipients were analyzed for donor cell Y chromosome contribution by peripheral blood DNA PCR at 4 months after injection. At a limiting dose of $10^{4}$ cells, more HSC activity was found in $\mathrm{Bcl}-2$ transgenic BM (Figure 6A) than in wild-type littermate controls. Frequency analysis was performed (Table 4), and HSCs were found to be increased 2.6-fold $(P<.03)$ in the Bcl-2-overexpressing mice. Furthermore, by flow cytometry on Bcl-2 transgenic BM $(\mathrm{n}=3)$, we found a 1.6- to 3.7-fold $(2.6 \pm 1.1)$ increase in the number of $\mathrm{c}-\mathrm{kit}^{+}$cells as compared with nontransgenic BM (not shown). Thus, Bcl-2 overexpression increases the number of BM HSCs.

Limiting dilution in vivo transplantation experiments with AGM and liver cells from $\mathrm{Bcl}-2$ transgenic and wild-type male embryos revealed that the HSC activity of E11 $\mathrm{Bcl}-2$ transgenic AGM cells (Figure 6B) was higher (10 repopulated of 25 recipients) than in transgenic littermate controls (only 2 of 19 recipients repopulated). Engraftment was high level (up to $100 \%$ donor derived), long term, and multilineage (not shown). By E12, HSC activity in transgenic AGMs was similar to that of the E12 nontransgenic AGM, but this may be due to saturating numbers of HSCs in the injected dose. Bcl-2 transgenic E12 liver also showed some increases in HSC activity when compared with nontransgenic liver at limiting injection doses (Figure 6C). Frequency analysis (Table 4) revealed that HSC numbers were significantly increased in the E11 AGM by a factor of $4.5(P<.02)$. Thus, Bcl-2 overexpression increases the number of functionally repopulating AGM HSCs.

To further check the potency of these midgestation HSCs, limiting doses of BM cells from the primary $B c l-2$ transgenic and nontransgenic AGM- and liver-engrafted recipients were injected into secondary recipients. $\mathrm{Bcl}-2$ transgenic secondary transplanted AGM cells showed potent HSC activity (Figure 6B, right side of 
A

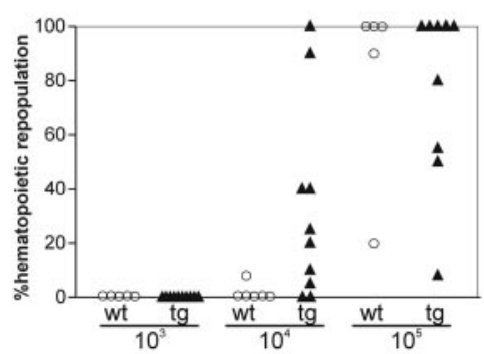

B

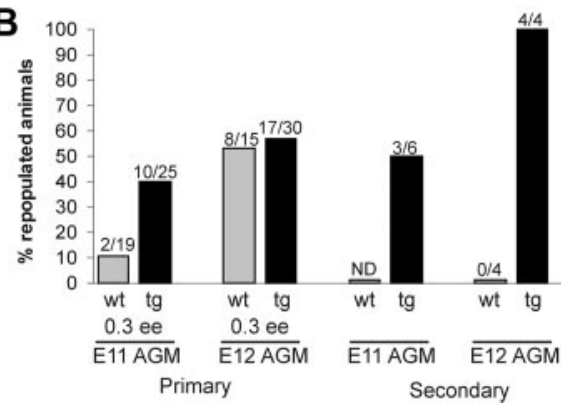

C

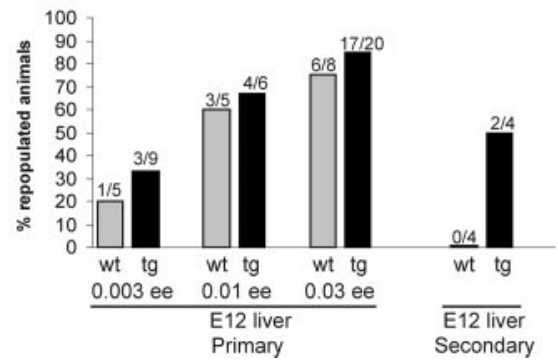

Figure 6. Increased HSC activity in the bone marrow, AGM, and liver of Bcl-2-overexpressing transgenic animals. (A) HSC activity in the BM of Bcl-2-overexpressing mice. Whole BM from a male Ln 479 transgenic (tg) and a nontrangenic (wt) littermate was injected at different limiting doses (103, $10^{4}$, and $10^{5}$ cells) together with $10^{5}$ female BM cells into irradiated female recipients. At 4 months after transplantation, the peripheral blood of the recipient was analyzed in a semiquantitative manner for male donor hematopoietic cells. Black triangles represent individual recipients engrafted with Bcl-2 BM, and gray circles indicate individual recipients engrafted with wt BM. Results of competitive repopulation experiments for Ln 479 transgenic and nontransgenic littermates are shown. A greater than $10 \%$ engraftment level in the peripheral blood was used as the criterion for positive HSC repopulation. Ln2 transgenic BM gave similar results (not shown). (B-C) Transplantations were performed with E11 AGM, E12 AGM Ln 479 transgenic ( $\mathbf{\square}$; panel B), and E12 liver cells ( $\mathbf{\square}$; panel C), as well as nontransgenic control cells (圆). The combined results of 2 independent transplantation experiments show the percentage repopulated recipients ( $y$-axis) and the number of mice positive/the number of total mice injected for each group. ee indicates embryo equivalents injected; and ND, not done. All recipients considered positive at more than 4 months after transplantation showed donor-derived cell engraftment levels exceeding $10 \%$ by semiquantitative PCR. In general, a higher percentage of repopulated recipients is seen with Bcl-2 transgenic midgestation AGM and liver cells than with wild-type littermate cells. Results of secondary transplantations are shown on the right. BM cells from primary recipients injected with E11 AGM, E12 AGM, and E12 liver were transplanted in limiting dilutions into irradiated adult secondary recipients. The percentage of repopulated recipients and the number of mice positive/the number of total mice injected are shown for each group. The BM cells of the primary recipients injected with E11 AGM, E12 AGM, and E12 liver cells that were used for secondary transplantation were $75 \%$ to $100 \%$ repopulated by donor-derived cells. Results were obtained at more than 4 months after transplantation by PCR analysis of peripheral blood DNA. Again, a higher percentage of repopulated recipients is seen with $\mathrm{Bcl}-2$ transgenic as compared with wild-type littermate cells.

panel), while nontransgenic cells provided no engraftment (combined data of transgenic secondary transplants: 7 repopulated of 10 transplanted as compared with nontransgenic transplants, 0 of 4). Similarly, Bcl-2 transgenic secondary transplanted liver cells showed HSC activity, while nontransgenic liver did not give rise to donor cell engraftment (Figure 6C, right side of panel). Thus, these transplantation data demonstrate that Bcl-2-overexpressing AGM and liver tissues possess higher HSC activity and self-renewal ability than nontransgenic tissues, strongly suggesting that apoptosis plays a role in the regulation of HSCs in the midgestation mouse.

\section{Discussion}

It has been widely accepted that a tight quantitative control of HSCs is essential in maintaining the appropriate and stable representation of progenitors and differentiated cells in the adult hematopoietic hierarchy. Because the blood system is highly dynamic, responds rapidly to trauma, and also constantly replenishes itself, cell survival and apoptosis play an important role in regulation of this tissue system. Our results show that, during development of the hematopoietic system within the embryo, these processes also appear to play a role.

It can be implied from the observed HSC increases in our $L y-6 E$ (Sca-1) $\mathrm{Bcl}-2$ transgenic mice that components of the $\mathrm{Bcl}-2$

Table 4. Frequency analysis of HSCs in embryonic and adult hematopoietic tissues

\begin{tabular}{lccccc}
\hline \multirow{2}{*}{$\begin{array}{c}\text { Tissue } \\
\text { transplanted }\end{array}$} & \multicolumn{2}{c}{ Nontransgenic } & & \multicolumn{2}{c}{ Bcl-2 trangenic } \\
\cline { 2 - 3 } \cline { 6 - 6 } \cline { 5 - 6 } & HSC frequency & HSC/ee & & HSC frequency & HSC/ee \\
\hline E11 AGM & $1 / 2.7 \times 10^{5}$ & 0.37 & & $1 / 0.6 \times 10^{5}$ & $1.70^{*}$ \\
E12 AGM & $1 / 0.4 \times 10^{5}$ & 2.54 & & $1 / 0.4 \times 10^{5}$ & 2.78 \\
E12 liver & $1 / 0.017 \times 10^{5}$ & 58.8 & & $1 / 0.013 \times 10^{5}$ & 76.9 \\
Bone marrow & $1 / 6.28 \times 10^{4}$ & NA & & $1 / 2.31 \times 10^{4}$ & NA \\
\hline
\end{tabular}

HSC frequencies were determined from the primary transplantation data in Figure 6 and were calculated by means of L-Calc software (StemCell Technologies, Vancouver, BC, Canada). ee indicates embryo equivalent; and NA, not applicable.

${ }^{\star}$ Statistical significance; $P<.02$ pathway leading to cell survival are intact and functionally relevant in these cells. Until our investigation, it was not known whether $\mathrm{Bcl}-2$ is normally expressed in this region. Our immunostainings have shown that $\mathrm{Bcl}-2$ protein is expressed in the midgestation AGM and, furthermore, by TUNEL analysis, that apoptosis is ongoing in this region. $\mathrm{Bcl}-2$ transcripts are found in both the aorta and the UGRs. While $\mathrm{TUNEL}^{+}$foci are found in the mesonephric tubules (indicating apoptosis), it appears that the apoptosis occurring in the region surrounding the dorsal aorta is limited to single cells. These data suggest that there is a tight regulation of apoptosis in this region, and we postulate that, in addition to $\mathrm{Bcl}-2$, other apoptotic regulators play a role in the balance between cell survival and apoptosis in the AGM.

We have found expression of the $B c l-x$ antiapoptotic regulator and the Bim proapoptotic regulator in the midgestation aorta and UGRs. Since the results of other researchers in adult hematopoietic cell subsets and tissues ${ }^{21}$ show only slight overlap in Bcl-2 and $\mathrm{Bcl}-\mathrm{x}$ in vivo expression patterns, these molecules may be expressed in different AGM cell subsets. Indeed, gene-targeted mutant mice show different phenotypes. ${ }^{12,22,44} \mathrm{Bcl}$-2-deficient mice complete embryonic development and show increased apoptosis in lymphocyte populations, and $\mathrm{Bcl}$-x-deficient mice die around E13 with extensive apoptosis of hematopoietic cells in the fetal liver. Interestingly, recent data show that concomitant loss of the proapoptotic Bim gene and the antiapoptotic $\mathrm{Bcl}-2$ gene allows normal physiologic functions, and thus, Bim counterbalances Bcl-2 activity. ${ }^{45}$ Moreover, Bim expression has been found in several hematopoietic cell lines, ${ }^{46,47}$ and Bim up-regulation correlates with increased apoptosis induced in E17 fetal liver cells upon hematopoietic growth factor withdrawal. ${ }^{48}$ Therefore, there are important roles for Bcl-2, Bcl-x, and Bim in regulating apoptosis in hematopoietic cells, and the intracellular ratios of these and other proapoptotic and antiapoptotic proteins are expected to play a critical role in setting the balance between cellular life or death. Semiquantitative transcriptional analysis of these 3 genes in the normal and Bcl-2-overexpressing AGM, aorta, UGRs, and liver suggests that the balance of proapoptotic and antiapoptotic molecules is also important during midgestation hematopoiesis. When 
$B c l-2$ is overexpressed in the aorta in transgenic embryos, a concomitant increase in Bim, but not $\mathrm{Bcl}-\mathrm{x}$, is observed. How this balance is achieved at the transcriptional level is unknown. Further studies should determine whether these 3 molecules (or other combinations) are expressed in the same population/subset of AGM cells and the precise balance between these proapoptotic and antiapoptotic molecules that leads to increased HSC activity in the mouse embryo.

We have shown here that $\mathrm{Bcl}-2$ overexpression increases the numbers of ${\mathrm{c}-\mathrm{kit}^{+}}^{+}$and Sca- ${ }^{+}$cells in the AGM, decreases their entry into the apoptotic pathway, and, more important, increases the numbers of functional HSCs beginning at midgestation in the AGM. HSC activity was significantly increased in the E11 AGMs from Sca-1 $\mathrm{Bcl}-2$ transgenic embryos (4.5-fold increase; $P<.02$ ). Such an increase was less apparent in transgenic E12 AGM and liver. However, when secondary transplantations were performed to confirm the self-renewal ability of AGM and liver HSCs, increased HSC activity was observed in the $\mathrm{Bcl}-2$ transgenic primary $\mathrm{BM}$ as compared with the nontransgenic recipients, suggesting that saturating numbers of HSCs were present in the primary $\mathrm{Bcl}-2$ engrafted recipient. Thus, $\mathrm{Bcl}-2$ overexpression affects the repopulating activity of the first AGM and liver HSCs. Whether Bcl-2 overexpression has a direct effect only on HSC number or has several related effects, such as enhancing engraftment through survival and/or influencing the cell cycle status of HSCs (as for adult BM HSCs), is yet to be determined. Importantly, whatever the effect of Bcl-2 overexpression on HSCs, these cells are normal, renew themselves, and contribute to long-term, multilineage repopulation. The fact that increased HSC numbers are found in the AGM, liver, and adult BM suggests the intriguing possibility that HSCs undergo apoptosis more often and much earlier than was previously appreciated.

Finally, in examining the validity of our Bcl-2 overexpression transgenic mouse model in the adult hematopoietic system, we found that $\mathrm{Bcl}-2$ overexpression occurs in the tissues and hematopoietic cells that are normally expected to express Sca-1..$^{31-35}$ Sca-1-directed Bcl-2 overexpression affects adult hematopoietic cells under both normal and stressful conditions, most likely by preventing them from entering the apoptotic pathway. As expected from the previous results of others, ${ }^{24,28}$ Sca-1-directed Bcl-2 overexpression results in radio-protection and in increases of $\mathrm{BM}$ HSC activity (as determined by in vivo transplantation). Frequency analysis revealed that BM HSC numbers were significantly increased in $\mathrm{Bcl}-2$ transgenic adults by a factor of 2.7. This increased BM HSC activity may be related to a lower susceptibility of the transgenic HSCs to entering into apoptosis during the engraftment of the recipient. Several studies have reported that Bcl-2 influences the cell cycle by blocking the transition from $\mathrm{G}_{1}$ to $\mathrm{S}-\mathrm{G}_{2}-\mathrm{M} \cdot{ }^{49,50}$ Since there is a correlation between the cell cycle status of HSCs and their ability to home to the recipient BM (see Jetmore et $\mathrm{al}^{51}$ and references therein), it is possible that altered cell cycle profiles could result in the facilitated engraftment we observed for Sca-1 Bcl-2-overexpressing HSCs. Nonetheless, the Bcl-2-related increase in HSC activity is also due to an increase in the absolute number of HSCs, since we have found more c-kit ${ }^{+}$cells in Bcl-2 transgenic BM (1.6- to 3.7-fold increase). This is in accordance with the findings of Domen et $\mathrm{al}^{9}$ in $\mathrm{H} 2 \mathrm{~K}-\mathrm{Bcl} 2$ mice in which the c-kit ${ }^{+}$lineage-negative $\left(\mathrm{c}-\mathrm{kit}^{+} \mathrm{lin}^{-}\right)$HSCs are increased 2.4-fold as compared with wild-type mice. Given the notion that Bcl-2overexpressing HSCs enter into apoptotic stages at a lower frequency and remain viable for longer periods of time, it may now be possible to isolate cell lines of this difficult-to-culture Sca- $1^{+}$ hematopoietic subset from the AGM and adult BM. Such cell lines would greatly facilitate molecular analyses of developmentally specific HSC genetic programs.

Taken together, our studies show that antiapoptotic and proapoptotic processes are intact, active, and functioning in the earliest expanding HSCs in the AGM region of the mouse embryo and that apoptosis/cell survival plays an important role in these first HSCs.

\section{Acknowledgments}

The authors thank the members of laboratory for helpful discussions and technical assistance, especially Drs S. Mendes, M. Peeters, and M. de Bruijn. We especially thank Dr C. Robin for her critical review of the manuscript and her expert contributions to the flow cytometric analysis.

\section{References}

1. Spangrude GJ, Smith L, Uchida N, et al. Mouse hematopoietic stem cells. Blood. 1991;78:13951402.

2. Lemischka IR. The haemopoietic stem cell and its clonal progeny: mechanisms regulating the hierarchy of primitive haematopoietic cells. Cancer Surveys. 1992;15:3-18.

3. Medvinsky A, Dzierzak E. Definitive hematopoiesis is autonomously initiated by the AGM region. Cell. 1996;86:897-906.

4. Müller AM, Medvinsky A, Strouboulis J, Grosveld F, Dzierzak E. Development of hematopoietic stem cell activity in the mouse embryo. Immunity. 1994;1:291-301.

5. Kumaravelu P, Hook L, Morrison AM, et al. Quantative developmental anatomy of definitive haematopoietic stem cells/long-term repopulating units (HSC/RUs): role of the aorta-gonad-mesonephros (AGM) region and the yolk sac in colonisation of the mouse embryonic liver [published correction appears in Development. 2003:130: 425]. Development. 2002;129:4891-4899.

6. Ema H, Nakauchi $\mathrm{H}$. Expansion of hematopoietic stem cells in the developing liver of a mouse embryo. Blood. 2000;95:2284-2288.

7. Morrison SJ, Hemmati HD, Wandycz AM, Weissman IL. The purification and characterization of fetal liver hematopoietic stem cells. Proc Natl Acad Sci U S A. 1995:92:10302-10306.

8. Schofield R. The relationship between the spleen colony-forming cell and the haemopoietic stem cell. Blood Cells. 1978;4:7-25.

9. Domen J, Cheshier SH, Weissman IL. The role of apoptosis in the regulation of hematopoietic stem cells: overexpression of $\mathrm{Bcl}-2$ increases both their number and repopulation potential. J Exp Med. 2000;191:253-264.

10. Evan G, Littlewood T. A matter of life and cell death. Science. 1998;281:1317-1322.

11. Meier P, Finch A, Evan G. Apoptosis in development. Nature. 2000;407:796-801

12. Nakayama K, Nakayama K, Negishi I, Kuida K Sawa H, Loh DY. Targeted disruption of Bcl-2 alpha beta in mice: occurrence of gray hair, polycystic kidney disease, and lymphocytopenia. Proc Natl Acad Sci U S A. 1994;91:3700-3704

13. Adams JM, Cory S. The Bcl-2 protein family: arbiters of cell survival. Science. 1998;281:13221326

14. Bouillet $P$, Huang DC, O'Reilly LA, et al. The role of the pro-apoptotic Bcl-2 family member bim in physiological cell death. Ann N Y Acad Sci. 2000; 926:83-89.
15. Strasser A, Puthalakath $\mathrm{H}$, Bouillet $\mathrm{P}$, et al. The role of bim, a proapoptotic $\mathrm{BH}$-only member of the Bcl-2 family in cell-death control. Ann N Y Acad Sci. 2000;917:541-548.

16. Cleary ML, Sklar J. Nucleotide sequence of a $\mathrm{t}(14 ; 18)$ chromosomal breakpoint in follicular lymphoma and demonstration of a breakpoint-cluster region near a transcriptionally active locus on chromosome 18. 1985;82:7439-7443.

17. Seto M, Jaeger U, Hockett RD, et al. Alternative promoters and exons, somatic mutation and deregulation of the $\mathrm{Bcl}-2-\mathrm{lg}$ fusion gene in lymphoma. EMBO J. 1988;7:123-131.

18. Evan GI, Vousden KH. Proliferation, cell cycle and apoptosis in cancer. Nature. 2001;411:342348.

19. Strasser A, Harris AW, Huang DC, Krammer PH Cory S. Bcl-2 and Fas/APO-1 regulate distinct pathways to lymphocyte apoptosis. EMBO J. 1995; 14:6136-6147.

20. Hockenbery DM, Zutter M, Hickey W, Nahm M, Korsmeyer SJ. BCL2 protein is topographically restricted in tissues characterized by apoptotic cell death. Proc Natl Acad Sci U S A. 1991;88: 6961-6965

21. Krajewski S, Krajewska M, Shabaik A, et al. Immunohistochemical analysis of in vivo patterns of 
Bcl-X expression. Cancer Res. 1994:54:55015507

22. Motoyama N, Wang F, Roth KA, et al. Massive cell death of immature hematopoietic cells and neurons in Bcl-x-deficient mice. Science. 1995; 267:1506-1510.

23. Linette GP, Grusby MJ, Hedrick SM, Hansen TH, Glimcher LH, Korsmeyer SJ. Bcl-2 is upregulated at the CD4+ CD8 + stage during positive selection and promotes thymocyte differentiation at several control points. Immunity. 1994;1:197-205.

24. Strasser A, Harris AW, Cory S. Bcl-2 transgene inhibits $T$ cell death and perturbs thymic self-censorship. Cell. 1991;67:889-899.

25. Katsumata M, Siegel RM, Louie DC, et al. Differential effects of Bcl-2 on T and B cells in transgenic mice. Proc Natl Acad Sci U S A. 1992;89: 11376-11380

26. Siegel RM, Katsumata M, Miyashita T, Louie DC, Greene MI, Reed JC. Inhibition of thymocyte apoptosis and negative antigenic selection in bcl-2 transgenic mice. Proc Natl Acad Sci U S A. 1992; 89:7003-7007.

27. Ogilvy $S$, Metcalf $D$, Print CG, Bath ML, Harris AW, Adams JM. Constitutive Bcl-2 expression throughout the hematopoietic compartment affects multiple lineages and enhances progenitor cell survival. Proc Natl Acad Sci U S A. 1999;96: 14943-14948.

28. Domen J, Gandy KL, Weissman IL. Systemic overexpression of $B C L-2$ in the hematopoietic system protects transgenic mice from the consequences of lethal irradiation. Blood. 1998;91: 2272-2282.

29. Spangrude GJ, Heimfeld S, Weissman IL. Purification and characterization of mouse hematopoietic stem cells [published correction appears in Science. 1989;244:1030. Science. 1988;241:5862.

30. Uchida N, Weissman IL. Searching for hematopoietic stem cells: evidence that Thy-1.1lo LinSca-1 + cells are the only stem cells in C57BL Ka-Thy-1.1 bone marrow. J Exp Med. 1992;175: 175-184.

31. Miles C, Sanchez MJ, Sinclair A, Dzierzak E. Expression of the Ly-6E.1 (Sca-1) transgene in adult hematopoietic stem cells and the developing mouse embryo. Development. 1997;124:537547.

32. Ma X, Robin C, Ottersbach K, Dzierzak E. The Ly-6A (Sca-1) GFP transgene is expressed in all adult mouse hematopoietic stem cells. Stem Cells. 2002;20:514-521.

33. Ma X, de Bruijn M, Robin C, et al. Expression of the Ly-6A (Sca-1) lacZ transgene in mouse haematopoietic stem cells and embryos. $\mathrm{Br} \mathrm{J}$ Haematol. 2002;116:401-408.

34. de Bruijn MF, Ma X, Robin C, Ottersbach K, Sanchez M-J, Dzierzak E. Hematopoietic stem cells localize to the endothelial cell layer in the midgestation mouse aorta. Immunity. 2002;16: 673-683.

35. Hanson P, Mathews V, Marrus SH, Graubert TA. Enhanced green fluorescent protein targeted to the Sca-1 (Ly-6A) locus in transgenic mice results in efficient marking of hematopoietic stem cells in vivo. Exp Hematol. 2003;31:159-167.

36. Nunez G, London L, Hockenbery D, Alexander M, McKearn JP, Korsmeyer SJ. Deregulated Bcl-2 gene expression selectively prolongs survival of growth factor-deprived hemopoietic cell lines. J Immunol. 1990;144:3602-3610.

37. Sinclair AM, Dzierzak EA. Cloning of the complete Ly-6E.1 gene and identification of DNase hypersensitive sites corresponding to expression in hematopoietic cells. Blood. 1993;82:3052 3062.

38. Sinclair A, Daly B, Dzierzak E. The Ly-6E.1 (Sca-1) gene requires a 3' chromatin-dependent region for high-level gamma-interferon-induced hematopoietic cell expression. Blood. 1996;87: 2750-2761.

39. Negrini M, Silini E, Kozak C, Tsujimoto Y, Croce $\mathrm{CM}$. Molecular analysis of mbcl-2: structure and expression of the murine gene homologous to the human gene involved in follicular lymphoma. Cell. 1987;49:455-463.

40. de Bruijn MF, Speck NA, Peeters MC, Dzierzak E. Definitive hematopoietic stem cells first develop within the major arterial regions of the mouse embryo. EMBO J. 2000;19:2465-2474.

41. Sanchez MJ, Holmes A, Miles C, Dzierzak E.
Characterization of the first definitive hematopoietic stem cells in the AGM and liver of the mouse embryo. Immunity. 1996;5:513-525.

42. Vermes I, Haanen C, Steffens-Nakken H, Reutelingsperger C. A novel assay for apoptosis: flow cytometric detection of phosphatidylserine expression on early apoptotic cells using fluorescein labelled Annexin V. J Immunol Methods. 1995; 184:39-51.

43. Codias EK, Cray C, Baler RD, Levy RB, Malek TR. Expression of Ly-6A/E alloantigens in thymocyte and T-lymphocyte subsets: variability related to the Ly-6a and Ly-6b haplotypes. Immunogenetics. 1989;29:98-107.

44. Veis DJ, Sorenson CM, Shutter JR, Korsmeyer SJ. Bcl-2-deficient mice demonstrate fulminant lymphoid apoptosis, polycystic kidneys, and hypopigmented hair. Cell. 1993;75:229-240.

45. Bouillet P, Cory S, Zhang LC, Strasser A, Adams JM. Degenerative disorders caused by Bcl-2 deficiency prevented by loss of its $\mathrm{BH} 3-$ only antagonist Bim. Dev Cell. 2001;1:645-653.

46. O'Connor L, Strasser A, O'Reilly LA, et al. Bim: a novel member of the Bcl-2 family that promotes apoptosis. EMBO J. 1998;17:384-395.

47. Huang DC, Strasser A. BH3-only proteins: essential initiators of apoptotic cell death. Cell. 2000 ; 103:839-842.

48. Dijkers PF, Medema RH, Lammers JW, Koenderman L, Coffer PJ. Expression of the pro-apoptotic $\mathrm{Bcl}-2$ family member Bim is regulated by the forkhead transcription factor FKHR-L1. Curr Biol. 2000;10:1201-1204.

49. O'Reilly LA, Huang DC, Strasser A. The cell death inhibitor $\mathrm{Bcl}-2$ and its homologues influence control of cell cycle entry. EMBO J. 1996;15: 6979-6990.

50. Vairo G, Soos TJ, Upton TM, et al. Bcl-2 retards cell cycle entry through p27(Kip1), pRB relative p130, and altered E2F regulation. Mol Cell Biol. 2000;20:4745-4753.

51. Jetmore A, Plett PA, Tong X, et al. Homing efficiency, cell cycle kinetics, and survival of quiescent and cycling human CD34(+) cells transplanted into conditioned NOD/SCID recipients. Blood. 2002;99:1585-1593. 